\title{
Violence Against Violence Against Women: An Avant-Garde for the Times
}

\section{Dianne Chisholm University of Alberta}

\begin{abstract}
While feminism has successfully alerted public reaction to violence against women, it must become more active in confronting, representing and transforming that violence. Against the highly publicized "culture of violence" presently terrorizing women across North America, feminism must mobilize an aggressive counter-culture, an avant-garde capable of putting audiences and readers "in touch" with endemic violence against women's responsiveness. A contemporary feminist avant-garde might model itself after the artistic activism of the historical avant-garde, including the tradition of manifesto art that has appeared sporadically in the 20 th century. In the wake of the "Montreal massacre," no such feminist avant-garde has emerged although national newspapers confirm a growing violence against women and feminists themselves. This author thus believes that the basis for a feminist cultural front exists, and that it must come forward now to activate solidarity in diversity.
\end{abstract}

\section{RÉSUMÉ}

Quoique le féminisme ait réussi à éveiller l'attention du public sur la violence contre les femmes, il doit devenir plus actif en faisant face à cette violence, en la représentant et en la transformant. En contraste avec la culture de violence qui fait couler beaucoup d'encre et qui et qui terrorise actuellement des femmes partout en Amérique du Nord, le féminisme doit mobiliser une contre-culture agressive, un mouvement d'avant-garde en mesure de sensibiliser les assistances et les lecteurs à la violence endémique contre les réactions des femmes. Un mouvement d'avant-garde féministe contemporain pourrait se modeler sur l'activisme artistique de l'avant-garde historique, y compris la tradition de l'art manifeste qui a fait surface sporadiquement au cours du $20^{\mathrm{c}}$ siecle. Aucun mouvement d'avant-garde féministe ne s'est manifesté depuis le «massacre de Montréal», bien que les journaux nationaux confirment l'existence d'une violence croissante à l'égard des femmes et des féministes elles-mêmes. L'auteure de cet article croit qu'il existe la base d'un front culturel féministe et que cette base doit maintenant se manifester pour éveiller la solidarité parmi une diversité de groupes.

It's time to stop the culture of violence in which two Canadian women are killed by their male partners each week, say members of a federal panel on violence against women.

"At some point this tolerance of violence, this culture of violence, must cease," said panel-member Daniel Lemieux, co-ordinator of the Quebec Coalition of Sexual Assault Centres, at a news conference Saturday.

"The time has come to change the mentality, the people are motivated enough to make an important change of direction." - The Canadian Press, February 16, 1992

They say, It is a great error to imagine that I, a woman, would speak violence against men. But we must, as something quite new, begin.... Monique Wittig, Les Guérillères 


\section{Feminist Culture in a Culture of Violence}

"W ITHIN THE REALM OF WHAT WE CALL 'social issues,' violence against women unquestionably emerged as a central theme in 1991," announced the Ottawa Citizen on the eve of the New Year (Davis-Barron 1991). "Feminists successfully pushed the issue into the mainstream. $\mathrm{Ca}-$ nadian society was ready to listen."

Emerging triumphant after thirty years of raising public conscience, feminism must now proceed to advance its campaign for political and legal intervention; the time is right, "the people are motivated." Even the federal government is compelled, as evidenced by the panel it has launched around the country. (Talk of a pyrrhic victory! Scoring the headlines with sexual and domestic violence is hardly good news for women.) Since the "Montreal massacre," feminism has pushed the Canadian press to feature such continuously current events as the anti-feminist backlash; sexual violence on North American campuses; the battering and killing of women by their male partners; harassment in the workplace; date rape; the suffering of survivors of sexual abuse; assaults on native women in both white and native communities; the violent consequences of criminalizing abortion; the Clarence Thomas hearings and the trials of William Kennedy-Smith and Mike Tyson; the unsettled and unsettling case of Helen Betty Osborne. ${ }^{2}$

That feminism today is "unquestionably" most effective in lobbying to make violence against women the major social issue in this country might also be a problem for feminism. In making sexual and violent assault on women arousingly newsworthy, thus statistically and graphically visible, feminism inevitably draws attention to women's physical, psychical, and social vulnerability and victimization. However justifiably committed to this drive for attention and intervention, feminism must, with no less urgency, confront the total impact of its campaign, looking beyond its determination to foreground men's culture of violence to the cultural effect it has on women. Feminism must see where the effective limits of this campaign are drawn and where it might backfire, in effect demoralizing and disempowering women through an unprecedented publication of terror.

Action is always met with reaction: defenders of the status quo charge feminism itself with creating this culture of violence. However, beyond "old boys'" resistance, there is the common woman reader to consider, who, without a solid background in feminist theory and a battery of subscriptions to feminist periodicals and social networks, is abandoned to the popular press. Reporting what sells with a liberal dose of objectivity, but with no political or ethical compulsion to make women's intellectual challenge and moral and psychological courage as newsworthy as their endemic rape, assault and abuse, the media only contributes to their terror. Determined to intensify their campaign, feminists might shrug off patriarchal reaction, which indulges in paranoiac fantasies of exposure and usurpation while enjoying positions of power most women will never even contemplate. However, can they afford to overlook the reaction of the great number of women whose fear of men and their power has been reified into a reign of terror? Can they overlook the great number of women who, instead of rallying to feminism to surmount this fear, express it by denying such violence exists? Feminist culture must be as forward as feminist lobbying: it is not enough for feminism to pervade the mass media with images of violence against women. While feminism is not responsible for the way the media draws attention to this violence for featuring Tyson's rape trial in the sports section where women themselves rarely feature, for example, or for giving feminism as much "bad press" as feature headlines, for another - it must take that responsibility anyway. Now that it has made the news by the force of its own reaction to violence against women, feminism must reappropriate this violence. It must mobilize more than reaction. It must actively stage this "culture of violence" for women's audiences in order to counter and transform it.

Feminism already exists as a broad cultural activity in Canada, at work in many public institu- 
tions, including the arts, the academies, the publishing and entertainment industries, and the mass media itself. As cultural activism, feminism must do more than make an appearance in these institutions: it must mobilize and deploy a cultural front for women even more effectively than it lobbies for attention to violence against women. As a reader and researcher in 20th-century feminist culture, I would urge feminist cultural workers to come forward as an avant-garde, declaring commitment to women's empowerment through the arts, forging strategic alliances with the lobbyists, as well as with the academics, the politicians, the shelter workers, and alienated or isolated radicals. To present an effective cultural force, feminism above all must, as Antonin Artaud said of avant-garde theatre, deploy an artistic avant-garde whose themes and techniques "correspond to the agitation and unrest of our times" (81).

\section{Cultivating Counter-Violence?}

I think that what matters is to be a warrior... And I think that action against men who hurt women is necessary. And I think that action against institutions which hurt women must be real. - Andrea Dworkin, Address to the "Women in a Violent Society" conference, Banff, Alberta, May 9-12, 1991

But how do we pass from the atmosphere of violence to violence in action? - Frantz Fanon, The Wretched of the Earth

In a culture of violence against women, is feminism's best strategy to cultivate counter-violence? A powerful affirmation of this strategy could be drawn from political theorists who advocate the use of counter-violence against demonstrably violent regimes. A feminist cultural avant-garde might study the most widely established and provocative of these political theorists, such as Georges Sorel, whose Reflections on Violence (1906) presents a detailed justification of the use of violence in socialist revolution, ${ }^{3}$ and Frantz Fanon, whose chapter "Concerning Violence" in The Wretched of the Earth (1961) passionately analyzes and argues for native violence in uprisings against colonialist terror. ${ }^{4}$ It might also refer to feminist political analysts who have at times advocated counter-violence. I recall Ti-Grace Atkinson's 1974 reading of the "battle between the sexes":

A "battle" implies some balance of powers, whereas when one side suffers all the losses ... that is called a massacre. Women have been massacred as human beings over history, and this destiny is entailed by their definition. As women begin massing together, they take the first step from being massacred to engaging in battle (resistance). (49)

In 1991, after twenty more years of massacre, Andrea Dworkin urgently reiterated this position of fighting back:

We are in a war. We have not been fighting back to win this war. We are in need of political resistance. We need it above-ground. We need it with our lawmakers, with our government officials. We need it with our professional women. We have been failing each other. We have to end the impunity that men have and they have virtual impunity to rape and to batter. (1991b, 8)

Psychotherapist Phyllis Chesler has argued that without mobilizing a capacity for violence of their own, women will never heal or transform their condition:

In terms of either immediate physical strength or the implied threat of physical, military, or economic strength, i.e., "political power," women have little power with which to either avoid or commit violence. Women traditionally are physically weak and politically powerless in a culture that values physical strength and its extended representation in the form of weaponry and money. Women, like men, must be capable of violence or self-defense before their refusal to use violence constitutes a free and moral choice, rather than "making the best of a bad bargain." (293)

Even groups of "established" women have advocated fighting back. For instance, an international workshop of politicians, administrators and educators held in Ottawa in $1984^{5}$ to discuss "strategies of power" slated the use of guerilla warfare on their future agenda (Gillett 200). 
Feminism has and does advance women's violence against violence against women, contrary to the conservative position which believes that violence is not feminine, and contrary to the liberal position which puts faith in humanist institutions governed primarily by men. But is the writing on the wall? Responses by women to the slaying of the fourteen women at Montreal's Ecole polytechnique, as recorded in Polytechnique, 6 décembre [The Montreal Massacre] show variation but none condone counter-violence. ${ }^{6}$ Perhaps as the period of mourning passes...?

One astute reader of our times, Grant McCracken, the director of the Institute of Contemporary Culture at the Royal Ontario Museum, reported to the Toronto Globe and Mail last December that, in such local sidewalk graffiti as "dead men don't rape," he construed an inevitable "women's call to arms" (A16). The article stresses his main point that such slogans "could be more than just a passing piece of graffiti," could signal women's "STRIKING BACK," and "the start of a movement in which we see the use of violence against men who commit violence against women." He backs up his intuition with "salient facts":

First, we know for certain that violence against women is no accident of our society. It is a structural feature of many domestic relationships. It is also an unmistakable feature in the public relationships between men and women. Public life in North America is marked by an endemic, persistent violence. Men commit it, women suffer it....

Second, we know that much of the violence goes unpunished....

Third, we know that North America has a tradition of "self-help" in certain public matters. When the police and the courts fail effectively to contain a public menace, people seek remedies of their own. Vigilante action stands ready to fill any vacuum left by the law. (A16)

He concludes that "under the circumstances, counterviolence inflicted by women on men may be inevitable."
McCracken is not alone in this sort of augury. Another cultural analyst, writing with the security of the greater American public in mind, predicts that as feminist and socialist demands "should exceed society's capacity to deliver reform, then violence or threat of violence is probable" and women's involvement in terrorism will "increase dramatically" (Georges-Abeyie, 81-82).

While this graffiti may be a sign of the times and may indeed incite women's more aggressive responsiveness, I am not convinced that the mobilization of women's counter-violence is inevitable. Otherwise, why must feminists repeatedly, decade after decade, attempt to convince women that violence, that fighting back, is a vital therapeutic, if not political, survival strategy? While it may seem logical, it is not very probable (contrary to what men say) that women will openly, massively respond to violence with violence. In a culture that values men's violence and women's passivity, women more "naturally" respond with terror than with an aggressive display of counter-power. ${ }^{7} \mathrm{De}-$ spite McCracken's claim that women no longer fall for the "argument that violence on the part of women would be answered by still more violence by men," women are acutely aware of men's antifeminist backlash. ${ }^{8}$ If the writing is on the wall, it is at least as threatening as it is inciting. I recall the graffiti recently scrawled on my colleagues' office doors in the University of Alberta's Humanities Centre, displaying such messages as "Kill the feminists!" and "Nice shooting Mark!" (Thomas, B3). ${ }^{9}$

With what transformative effect would women deploy their counter-violence? Is it possible, in our postcolonial age, for women to resolve with violence what Fanon describes as the "circle of hate," the vicious circle of "terror, counter-terror, violence, counter-violence"? (89). Have they not learned from their voluntary or necessary involvement in terrorist activities that "in all armed struggles, there exists what we might call the point of no retum"? (89). In this age of poststructuralism, when violence has been discovered at work throughout the socio-symbolic system, in the oppressive admi- 
nistration of power and knowledge (Foucault), in the structures of "master" discourse (Lacan), in the hegemonic construction of identity (Derrida, Irigaray), in the dialectical imperialism of modem European philosophy (Hoffman), in the global grid of the State military machine (Deleuze and Guattari), in the multinational microworlds of cyborg technology (Haraway), how can any armed rebellion initiate radical subversion? How could women's militant counter-violence, after overcoming a certain muscular timidity, challenge with open physical combat something as entrenched and abstract as the violence of humanism which, as Foucault says, "prohibits the desire for power and excludes the possibility of power being seized"? How, without mobilizing an attack on the "theory of the subject"? -

by a "desubjectification" of the will to power (that is, through political struggle in the context of class warfare) or by the destruction of the subject as pseudosovereign (that is, through an attack on "culture": the suppression of taboos and the limitations and divisions imposed on the sexes... (Foucault 221-22)

In the context of feminist analysis which acknowledges systemic violence against women, how can vigilantism and terrorism be pronounced an effective counterforce? Is it not vital for women that they mount either collective class action against men or guerilla warfare against the culture of male violence? When men's physical violence against women is frequently discovered to be an effect of, not a cause for, the intervention of the (father's) law, when it is readily apparent that violence against women is administered, not just by the courts, but systemically, through the institutions of sexual difference, is it not timely for women to master a pen that is far mightier than the sword? When Daniel Lemieux, of the federal panel on violence against women, calls for an end to "this tolerance of violence, this culture of violence," does he have women's violence against culture in mind?

\section{Feminist Avant-Garde Art: Aesthetic Activism?}

\begin{abstract}
The radical feminist investigations of literary form and social discourse have the potential to be the most significant expression of a revitalized avant-garde sensibility in the postmodern era, precisely because they bring together an aggressive aesthetic activism and a social collectivity that sees itself acting in society and its history. - Charles Russell, Poets, Prophets, and Revolutionaries
\end{abstract}

Despite the abundance of critical literature condemning avant-garde art to obsolescence (Bürger) or to the commodity fetishism of late capitalism (Fiedler), a very strong case can be made for a feminist avant-garde today. However, if the idea of such an art commonly denotes little more than commercial opportunism and modernist aestheticism, what possible appeal could a "feminist avantgarde" have for the "committed artist"?

Supposing it needs defending, a contemporary avant-garde might do well to recall the historical avant-garde and its outspokenly activist, if paradoxical, commitment to social and cultural transformation. According to theorist and historian Charles Russell, "the avant-garde wants to be more than a merely modernist art, one that reflects its contemporary society; rather, it intends to be a vanguard art, in advance of, and the cause of, significant social change" (15-16). While modernists express a disaffection for their times, devoting ingenious textual innovation to reproducing perceived social and psychological symptoms, avantgarde writers and movements act on the "belief that innovation in the form and language of art have social significance, either by their independent effects on the individual's or group's perception, knowledge, and behavior, or in association with the work of other activist members of society" (16). The avant-garde accordingly acclaims "the special attributes of imaginative language which makes it a 
particularly powerful form of instrumental discourse," and determines to use it to "make us see the world differently and act to transform it" (24). Social theories, such as those propounded by Pierre Bourdieu, outline a significant field of action for the artistic avant-garde:

\begin{abstract}
the symbolic revolution, which overturns mental structures and deeply upsets people's minds - which explains the violence of the reactions of bourgeois critics and public may be called the revolution par excellence. The critics, who perceive and denounce the avant-garde painter as a political revolutionary, aren't altogether wrong, even if the symbolic revolution is doomed, most of the time to remain confined to the symbolic domain. (149)
\end{abstract}

Semiotic theories, such as outlined by Teresa de Lauretis, explain how feminist avant-garde art could take this social theory much further by not only explaining but also intervening in the cultural (re)production of meaning. ${ }^{10}$

However far in advance of popular and/or traditional culture the avant-garde perceives itself to be, it remains "in touch" with the main body of society. ${ }^{11}$ While it "adopts an explicitly critical attitude, and asserts its distance from, the dominant values of that culture," the avant-garde also "reflects the writers' and artists' desire that art and the artist may find or create a new role within society and may ally themselves with other existing progressive or revolutionary forces to transform society" (Russell 4). "Invariably," Russell observes, "avant-garde writers tum toward the examples of science and radical politics to find support for their activist aesthetics" (26).

Avant-garde art proposes to be a "vanguard art" but differs from most socialist vanguards in its violence. The term "avant-garde" is, of course, military in origin and enters into modern usage shortly after the French Revolution in the proJacobin military journal, L'Avant-garde de l'armée des Pyrennées orientales (Russell 16). Serving as "shock troops," the military avant-garde "advanced before the main body to disrupt the enemy's lines, and, usually with great loss to themselves, insuring the success of those who followed" (16). When the term was later appropriated by utopian socialists, it lost its violent cutting edge. "The socialists' theories lacked the aggressive aspects of the military metaphor," invoking an "organic evolution of the new society" instead of targeting "the enemy to be vanquished" (16).

The artistic avant-garde fights on two fronts: against the establishment and for a future culture, with emphasis on destruction rather than reconstruction. "Since the future is unknown and often unimaginable, the nihilistic impulse in the avantgarde artwork is often the most dramatic expression of avant-garde desire" (Russell 34). An avantgarde artist deploys her or his primary strategies of disruption and disorientation, hoping that "the experience of disorientation may in itself provide the desired perceptual and conceptual freedom, if he believes as did many of the dadaists, that there are not adequate grounds upon which to build an alternative system of art" (34). In a "culture of violence," however, avant-garde disruption and disorientation must exceed the aesthetic conventions and audience expectations of violence. Moreover, the artistic avant-garde directs its violence not only against cultural convention and complacency but also against itself, disbanding or subverting itself before degenerating into vangardism. "If it is to be activist," the avant-garde "must lead beyond itself" (38), destroying or surpassing artworks and manifestos which "announce and create" the possibilities of a radical new art.

Taking its departure from the historical avantgarde, a contemporary feminist avant-garde would militate violently against established culture, targeting not just conventions and expectations of the artistic establishment, but more particularly, the "culture of violence against women," including the status quo's complacency towards or complicity with that culture. It would forge brave new alliances with other progressive groups, such as the organizers of the 1984 "Strategies for Power" conference in Ottawa, and those of its 1985 sequel, "Pouvoirs et contre-pouvoirs [Powers and counterpowers]" in Montreal (Cohen 13), ${ }^{12}$ as well as with 
the organizers of conferences on violence against women such as the one held in Ottawa in March 1992. ${ }^{13}$ It would advance on two fronts: negative and creative, and it would disrupt and disorient in excess of the violence systemically and endemically imposed on women. ${ }^{14}$ It would subvert or destroy itself after announcing and creating the possibilities of a radical new art and society for the "main body" of feminist pedagogy and media to cultivate.

\section{Countering Violence with a Violent Difference}

If feminists were to effectively deploy a cultural avant-garde against the culture of violence against women, they would have to know how to target audiences no less strategically than they would know how to explode the social text. As Russell $A$. Berman observes, avant-garde violence works on an audience as well as in language and performance:

The specific characterizations of avant-gardist aesthetic activity share this tone: provocation and shock. The relationship both to the established institution and to the contemporary public is in no way peaceful.... Provocational artists, destroying aesthetic values, antagonize a threatened public which responds with violence. (186)

To be subversive and not self-destructive, the violence feminism provokes should be deployed so as to destroy the reactionary reflex that lashes back at women. Feminism must be especially rigorous in selecting audiences, aiming its most provocative de(con)structions, not at women who perhaps suffer from over-sensitization to discursive/media violence, ${ }^{15}$ but at sexist institutions and their administrators, with the power to press shock and horror into radical reform.

Operating on the premise that men's violence against women is a symptom of encultured violence and not a motive in itself, feminist avant-gardes should aggressively theorize - break down and eradicate - the process of that enculturation. Such "violent" theorization already exists in the work of Luce Irigaray. In "The Power of Discourse and the
Subordination of Woman," Irigaray analyzes the rhetoric of "sexual indifference" and "logic of the same" that structures philosophical discourse and its derivatives (legal, political, academic discourses) so that women, as speaking subjects, are systematically denied positive and specific self-reference: "the 'feminine' is always described in terms of deficiency or atrophy, as the other side of the sex that alone holds a monopoly on value: the male sex" (1985a, 118-19). Against this systemic discrimination, she offers a rigorous program of interrogation, exposure, intervention and ...destruction. Targeting the foundational discourse of philosophy, feminist analysts must account for "the power of its systematicity ... its position of mastery" (122), ${ }^{16}$ after which, "what remains to be done ... is to work at 'destroying' the discursive mechanism" (124). ${ }^{17}$

Irigaray's program of destruction is as intricate and strategic as her program of analysis: women must introduce themselves into this discourse by playing up the rhetorical role of "the feminine." By repeating and interpreting the way in which feminine signifiers define lack, deficiency, or negation, women readers-writers could signify a "disruptive excess" (126). This "style" or "writing" of women, she asserts, "tends to put the torch to fetish words, proper terms, well-constructed forms" in which women's potential for symbolic self-reference is trapped. Such a style "resists and explodes every firmly established form, figure, idea, or concept" (126). She calls this a "feminine" style since it performs the conventional role of mirroring masculine significance against a foregrounded background of feminine irrationality, formless materiality, and figurational blankness. However, in its aim to destroy established discursivity, this style is exceptionally avant-garde. In "Any Theory of the 'Subject' Has Always Been Appropriated by the 'Masculine,"' Irigaray is thoroughly terroristic:

Turn everything upside down, inside out, back to front. Rack it with radical convulsions, carry back, reimport, those crises that her "body" suffers in her impotence to say what disturbs her. Insist also and deliberately upon those blanks in discourse which recall the places of her exclusion and which, by their silent plasticity, ensure the cohesion, the articulation, the coherent ex- 
pansion of established forms. Reinscribe them hither and thither as divergencies, otherwise and elsewhere than they are expected, in ellipses and eclipses that deconstruct the logical grid of the reader-writer, drive him out of his mind, trouble his vision to the point of incurable diplopia, at least. Overthrow syntax by suspending its eternally teleological order, by snipping the wires, cutting the current, breaking the circuits, switching the connections, by modifying continuity, alternation, frequency, intensity. $(1985 \mathrm{~b}, 142)$

Irigaray's avant-garde is more negative than creative. As she sees it, feminism must first blast through the discursive systematicity of sexual indifference so that women can enter into cultural and social dialogue and begin to articulate and negotiate power on their terms. While the violence of feminist deconstruction is aimed at the masculist philosopher, ${ }^{18}$ what becomes of the violence she provokes in women readers-writers? The questions Irigaray urgently asks of Jacques Derrida could be asked of Irigaray herself: "where has the violence gone when the deconstructor deconstructs? Is deconstruction itself violent? Or does it allow another violence to continue unchecked?" (Whitford 131).

The analytic violence with which Irigaray provokes her feminist readers may be the force which mobilizes their efforts to synthesize women's identity. "Both Derrida and Irigaray would see male identity - the construction of the male subject as 'violent' and hierarchical," Whitford observes, but for Irigaray, it is not just a question of deconstructing, but also of "reorganizing the economy.... of constructing the fragmentary feminine, binding together the scraps into a cohesion that is less destructive for them" (137). ${ }^{19}$ However, does the creative front of the feminist avant-garde necessarily entail the reconstruction of women's identity, even if that identity is something quite different from masculine subject construction? ${ }^{20}$ Is the reconstruction of women's identity a function of the feminist avant-garde or is such a project more appropriately assigned to the "main body" of feminism? If reconstructing identity is not an appropriately avant-garde activity, should it be considered an activist strategy at all? In answer to the initial question, "where does the violence provoked by feminist deconstruction in feminist audiences go?" should we not immediately answer "into the empowerment of women"? $?^{21}$

\section{A Poetics of Empowerment?}

A feminist avant-garde must deploy both negative and positive violence: against the culture of violence against women and for the cultural empowerment of women. Two avant-garde writers who work this double front of deconstruction and empowerment are African-American poet Audre Lorde, and French prose-poet Monique Wittig.

In Sister Outsider, Lorde advocates the use of eroticism against men's pornographic culture which has taught women to "suspect this resource, vilified, abused and devalued" $(1984,53)$. When she speaks of eroticism, she speaks of a creative will to power, buried in women's bodies and body politic: "an assertion of the lifeforce of women ... the knowledge and use of which we are now reclaiming in our language, our history, our dancing, our loving, our work, our lives" (55). Contrary to militant scepticism - "what do you mean, a poetic revolutionary, a mediating gunrunner?"' (56) - poetry empowered by women's eroticism is politically empowering. Used effectively in poetry, eroticism mobilizes women's affirmative will, "the yes within ourselves" (57), against and beyond a culture of negation. When "in touch with the power of the erotic within ourselves, and allowing that power to inform and illuminate our actions upon the world around us," Lorde testifies, "then we begin to be responsible to ourselves in the deepest sense.... We begin to give up, of necessity, being satisfied with suffering and self-negation...."122

Because the language of love and desire is, for women, so systematically bound up in discourses of subjection, a feminist avant-garde poetics must create a new lovers' discourse. Lorde's eroticized and feminized black power elaborates a project of appropriation begun years earlier by French feminist Hélène Cixous, whose "laughing medusa" manifesto declares that: 
men have committed the greatest crime against women. Insidiously, violently, they have lead them to hate women, to be their own enemies, to mobilize their immense strength against themselves, to be the executants of their virile needs. They have made for women an antinarcissism! A narcissism which loves itself only to be loved for what women haven't got! They have constructed the infamous logic of antilove. We the precocious, we the repressed of culture, our lovely mouths gagged with pollen, our wind knocked out of us, we the labyrinths, the ladders, the trampled spaces, the bevies - we are black and we are beautiful. (248)

In addition to advocating the use of eroticism as a strategy of empowerment, Lorde advocates the use of anger $(1984,124-33)$. Poetic use of anger is the mobilizing strategy of The Black Unicorn: Poems (1978). From the heraldic title poem "The Black Unicorn" to the revelatory poetics of "Power," one of the last poems in the book, Lorde intensifies her discourse of arousal and outrage. All the poems function as manifestos, declaring war on "the oppressor's language" ${ }^{23}$ and displaying a growing awareness of the power of poetry to mediate and mobilize black women's anger: "I am lost/ without imagery or magic/ trying to make power out of hatred and destruction" $(1978,108)$. Consider these two stanzas from "The Women of Dan Dance With Swords in Their Hands To Mark the Time When They Were Warriors":

I do not come like a secret warrior with an unsheathed sword in my hand hidden behind my tongue

slicing my throat to ribbons

of service with a smile

while the blood runs

down and out

through holes in the two sacred mounds

on my chest.

I come like a woman

who I am

spreading out through nights

laughter and promise

and dark heat

warming whatever 1 touch

that is living consuming

only

what is already dead. (14-15)

With blazing fury, this verse sets the reader burning, but not without an "objective correlative." In the first stanza, a figure of the poet-warrior rises phoenix-like out of a de(con)structive image of domestic femininity, whose unmasked "service with a smile" reveals her brutally desecrated body. In the final stanza, she announces her "coming" with a volatile passion which simultaneously kindles her will to live and destroys what is most dead(ly) about the enemy: the cold, abstracting reason of his enlightened white mythology. When the poem ends, her passion is not consumed but spreading, entreating the reader to bask in the holocaust of a black woman's armageddon. Such inscription of anger figures rather than incites the readers' violence, igniting outrage against a socio-symbolic order instead of sparking indiscriminate riot.

Like Lorde's warrior poems, Monique Wittig's Les Guérillères uses poetic language to mediate and mobilize the power of women's wrath. A sequence of prose poems flanked by pages bearing names of female guerilla fighters in phalanxes of bold capitals, Les Guérillères at once deploys an antidiscursive poetics and an allegorical revolutionary front. This is more than utopian fiction, spurring the reader's deconstructive imagination, her passion for separatism, revolution and reconstruction. The initiation of violence is at first slow, but gradually accelerates into global war:

The women say they have learned to rely on their own strength. They say they are aware of the force of their unity. They say, let those who call for a new language first learn violence. They say, let those who want to change the world seize all the rifles. They say that they are starting from zero. They say that a new world is beginning. (85)

Mobilization does not come easily to the women. They must first reclaim their bodies through the dithyrambic eroticism of dance until step by step their thythmic footwork articulates their collective, nihilistic fury: 
Begin the dance. Step forward lightly, move in a circle, hold each other by the hand, let everyone observe the rhythm of the dance. Spring forward lightly. The ring of dancers must revolve so that their glance lights everywhere. They say, It is a great error to imagine that I, a woman, would speak violence against men. But we must, as something quite new, begin the round dance stamping the feet in time against the ground. They say rise, slowly twice clapping your hands. Stamp the ground in time, $\mathrm{O}$ women. Now turn to the other side. Let the foot move in rhythm. (98-99)

The women make warlike gestures, approaching and retreating, dancing with their hands and feet. Some hold bamboo poles sorghum stems wooden batons the long ones representing lances and great halberds, the short ones double-edged swords or ordinary sabres. Dispersing by gates and paths they jostle each other impetuously. Their violence is extreme. They crash each other with bravura. No one can restrain them. (99)

This process is bolstered by sacred writings called "feminaries," whose "use of the erotic" emblazons the vulva in ritual arousal: ${ }^{24}$

The women say that the feminaries give pride of place to the symbols of the circle, the circumference, the ring, the $O$, the zero, the sphere ... as symbols of the vulva. (44-48)

Sun that terrifies and delights/ multicolored iridescent insect you devour yourself in night's memory/ blazing genital/ the circle is your symbol/ you exist from all eternity/ you will exist for all eternity. At these words the women begin to dance, stamping the ground with their feet. They begin a round dance, clapping their hands, giving voice to a song from which no coherent phrase emerges. (52-53)

Critical exposés of phallogocentricism raise such anger $^{25}$ the women are able to launch a violent onslaught of discursive retaliation, destroying lifelong habits of feminine deference and solicitude:

The women menace they attack they hiss the men they revile them jeer at them spit in their faces scoff at them provoke them flout apostrophize them mishandle them are abrupt with them they speak coarsely to them execrate them call them down curses on them. They are possessed by such utter fury that they boil with anger tremble choke grind their teeth foam blaze rage and fume leap vomit run riot. They call them to account admonish them put a knife to their throats intimidate them show them their fists they thrash them do violence to them acquaint them with all their grievances in the greatest disorder they sow the seed of discord here and there provoke dissension among them divide them ferment disturbances riots civil wars they treat them as hostile. Their violence is unleashed they are in a paroxysm of rage, in their devastating enthusiasm they appear wildeyed hair bristling clenching their fists roaring rushing shrieking slaughtering in fury one might say of them that they are females who look like women when they are dead. $(117-18)^{26}$

Wittig's guérillères eventually mobilize a warrior clan whose battle proceeds according to plans which prefigure Ti-Grace Atkinson's "Strategies and Tactics" for "political lesbians": fifty pages of flow charts mapping the penetration, occupation and destruction of territory ruled oppressively by men (135-89). ${ }^{27}$ These guérillères also prefigure Deleuze and Guattari's nomadic war machine, whose postmodern character borrows heavily from ethnology and mythology. For them, as for Wittig, the ancient Amazons present a future model for conceptualizing and tracing the movements of the political avant-garde (Deleuze and Guattari 355).

The Amazons deploy their impassioned violence with furious speed and shifting formations, ${ }^{28}$ while the Military commands conscripted labour with heavy-handed discipline and organizational immobility. ${ }^{29}$ Nomadic space and movement embodies an affirmative will to power, whereas the State administers a coercive counterpart. Against the Military's occupation of a regimental grid, which stops life-forces in their flow and dams the death-drive into hierarchies of power and subjection, the nomadic war machine "draw[s] a creative line of flight, the composition of a smooth space and the movement of people in that space" (Deleuze and Guattari 422). At war, they battle with wholly different objectives: the guerillas wish to destroy domination while the State wishes to extend it (423). 
Les Guérillères also reads as a poetic deployment of the violence Fanon advocates for colonized peoples. As in his model native uprising, Wittig's "women native others" launch absolute war: negotiation with the phallocratic colonizers is out of the question. As Fanon says:

To break up the colonial world does not mean that after the frontiers have been abolished lines of communication will be set up between the two zones. The destruction of the colonial world is no more and no less than the abolition of one zone, its burial in the depths of the earth or its expulsion from that country. (41)

The cutting edge of Les Guérillères lies not in its incitement to armed insurrection but in its poetic efficacy. Wittig disputes Fanon's argument that colonized peoples must of necessity rid themselves of their belief in the potency of art. Only through armed uprising, Fanon asserts, do the colonized emerge from their "imaginary maze" where they have been "a prey to unspeakable terrors yet happy to lose themselves in a dreamlike torrent." Accordingly, mobilization is diverted through ritual theatrics where "the most acute aggressivity, the most impelling violence are canalized, transformed, and conjured away ... [in] the huge effort of a community to exorcise itself, to liberate itself, to explain itself" (57). ${ }^{30}$ In violent rebellion, however, "such a people becomes unhinged, reorganizes itself, and in blood and tears gives birth to very real and immediate action" (56). The instigator of native uprising? - ultimately the abusive violence of the colonizer:

[T] he native's back is to the wall, the knife is at his throat (or, more precisely, the electrode at his genitals): he will have no more call for his fancies... The native discovers reality and transforms it into the pattern of his customs, into the practice of violence and into his plan for freedom. (58)

Wittig's dramatization of the violent deployment of (avant-garde) art challenges Fanon's argument that (native) art only serves to mystify and dissipate energies. Her guérillères use ritualized fantasy, theatre, and dance as powerful strategies of counter-cultural mobilization. For them, it is not the oppressor's violence but their own, recovered and embodied in lyrical and physical culture, which provokes the women to revolution.

Wittig structures her book contrary to conventional utopian form so that it ends at the moment of peak mobilization when the women have triumphantly abolished the patriarchal State, destroyed all their captives, and opened a whole new territory for nomadic cultivation. Mourning for their dead and greeting an altogether different breed of men, they gather sufficient affective power for building a brave new world. Instead of displaying battle fatigue or post-war bliss, the female warriors are fired up with new energy released through demobilization. As with Lorde's warrior-poems, Wittig's writing rouses readerly affects without diffusing them in wistful postfeminist dreams.

Reading Wittig and Lorde, it becomes clear that a feminist avant-garde art must use a medium that is as effective as inciting polemic. As Lorde announces: "Unless I learn to use/ the difference between poetry and rhetoric/ my power too will run corrupt as poisonous mold/ or lie limp and useless as an unconnected wire" (109). Unless feminist avant-garde art learns to use the violent poetry to wrench culture out of the vicious circle of violent rhetoric, only forces of reciprocating annihilation will be raised. ${ }^{31}$ What "the women say" in every passage of Les Guérillères, what the poet declares in "A Woman Speaks" in Black Unicorn are lyrical manifestos that have the power not only to provoke but, more importantly, to create feminist audiences counter-cultures.

\section{Feminist Manifestos: Lost Legacies, New Traditions}

Why should manifesto art be the chosen medium of a feminist avant-garde? As Grant McCracken says of graffiti, "next to speech, there is no faster way into public consciousness." Like graffiti, manifestos can be "cheap, quick, and when the sentiment is right, a powerful call to arms" (A16). Manifesto art is perhaps a sophisticated form of graffiti, not for writing on the wall (because the text is too long) but for easy distribution and consumption in the form of pamphlets, leaflets, newspapers, like the 
manifesto ad recently circulated in the New York Times by the African American Women In Defense of Ourselves in "protest, outrage, and resistance" over Clarence Thomas's recent appointment to the U.S. Supreme Court (Nadasen 31).

Violence and precision are the effective features of manifesto art according to Marjorie Perloff, who notes how the historical avant-garde "adopted the violent thetoric of contemporary political manifestos" (92). Reviewing the rise of Italian futurism, she locates Marinetti's "cult of energy, aggressiveness, violence, and heroism" in "a new urban mass art of heroic violence and nationalism" $(89,85)$. Commenting on his 1909 manifesto, she writes:

war is made to look like the necessary prelude to a new world composed of "great crowds excited by work," of "polyphonic tides of revolution in the modern capitals," of the "vibrant nightly arsenals and shipyards blazing with violent electric moons." Images of sound, color, and kinetic motion are foregrounded, the rhetorical strategy of the manifesto being to minimize the possibilities for rumination on the reader's part. (89)

Adding to this lyrical violence, she continues, is a "generic rupture," exploding "the distinction between 'literary' and 'theoretical' texts" (114-15). ${ }^{32}$

We might trace the colourful kinetic violence and generic rupturing of Wittig's Les Guérillères to Marinetti's manifestos, ${ }^{33}$ but it is not necessary to limit the source of feminist manifesto art to men's historical avant-garde - which was frequently virulently antifeminist. Consider the passages of Marinetti's manifesto which Perloff does not quote:

We will glorify war - the world's only hygiene - militarism, patriotism, the destructive gesture of freedom-bringers, beautiful ideas worth dying for, and scorn of women.

We will destroy the museums, libraries, academies of every kind, will fight moralism, feminism, every opportunistic or utilitarian cowardice. (Russell 89)

By 1914, the disaffected futurist Mina Loy wrote her "Feminist Manifesto," appropriating Marinetti's violent rhetoric to arouse women to a eroticopolitical awakening. Here are some excerpts:

The Feminist Movement as instituted at present is INADEQUATE.

Women, if you want to realize yourselves (for you are on the brink of a devastating psychological upheaval) all your pet illusions must be unmasked. The lies of centuries have got to be discarded. Are you prepared for the WRENCH?

There is no half-measure, no scratching on the surface of the rubbish heap of tradition. Nothing short of Absolute Demolition will bring about reform. So cease to place your confidence in economic legislation, vice-crusades and uniform education. You are glossing over REALTTY. $(269)^{34}$

Perhaps more ambitiously than Marinetti, Loy develops the art of inscribing manifestos into poetry, inadequately anthologized as "satirical." Apropos of Perloff, however, it may be argued that women's tradition of writing lyrical manifestos goes back as far as Emily Dickinson. Her "My Life had stood - a loaded gun" has recently become something of a cause célèbre among warring factions of feminist postmodernists who, like Susan Howe, historicize it as a brave first testament of woman's will to power ("written in a time of civil war, by a woman with little formal education, ... nearly twenty years before Friedrich Nietzsche's metaphysical rebellion" [34]) and antifeminists who, like Camille Paglia, diagnose it as symptomatic of a virulently decadent, sadomasochistic romanticism.

Women associated with historical avant-garde movements, but marginalized by the male majority on the grounds of their gender (Suleiman 11-30), inscribed manifestos into their verse. The extraordinary violence of H.D.'s "Sea Garden" poems, ${ }^{35}$ of Sylvia Plath's "Ariel" poems, ${ }^{36}$ of Diane Di Prima's "Revolutionary Letters" ${ }^{\text {"37 }}$ may be read, not as symptoms of feminine sadomasochism, but as hidden tenants of feminist manifestos - too violent to be feminine, and aimed too directly against masculinist "cults of virility" to meet the approval of avant-garde men or find formal incorporation into their official polemical writings. 
Not until the 1970s does a feminist avantgarde explicitly emerge, complete with manifestos advancing violent change on both political and cultural fronts. The early part of this movement is spearheaded by manifestos authored by radical American feminists, excerpts of which were collected and disseminated in Robin Morgan's popular anthology, Sisterhood is Powerful (1970). At the same time, in France, the Mouvement Liberation Féministes was actively disrupting the établissement with its own barrage of manifestos. These were collected, translated, and transported to the English-speaking world primarily through the vehicle of Elaine Mark and Isabelle de Courtivron's paperback edition of New French Feminisms (1980/ $81),{ }^{38}$ which includes a section entitled "Manifestos - Actions," although every section ("Introductions," "Beginnings," "Demystifications," "Wamings," "Creations," "Utopias,") reads like a battery of manifestos. Passages from Cixous, Irigaray and Wittig and many others representing the various avant-gardes of the $M L F$ can be found here, but of these texts, Cixous's "Laugh of the Medusa" elicits most critical attention as a manifesto. According to Susan Rubin Suleiman, it is:

the closest thing to an avant-garde manifesto written from an explicitly feminist perspective. True to the genre of the manifesto, it is written by an "I" who represents a group ("we," in this case women); it alternates between the aggressive (when addressing the hostile "straight" reader) and the hortatory (when addressing the other members of the group), and it suggests a program that implies both a revolutionary practice of writing and the disruption of existing cultural and social institutions and ideologies. ${ }^{39}$

The most outspoken excerpt in the American anthology is from Valerie Solanis's S.C.U.M. [Society for Cutting Up Men] Manifesto, first published in 1967/68 and calling for immediate criminal (versus civil) disobedience by "dominant, secure, self-confident, nasty, violent, selfish, independent, proud, thrill-seeking, free-wheeling arrogant females, who have free-wheeled to the limits of this 'society' and are now ready to wheel on to something far beyond what it has to offer"
(580). Solanis advocates women's mobilization in place of dropping out, since dropping out is precisely what the system wants - "the nonparticipation, passivity, apathy, and non-involvement of women" (581). She calls for mass rebellion by over half of the country's work force that would see the destruction of the patriarchy "within a year" (581). In keeping with Fanon, she calls for the complete elimination of the colonizer by murder and violent uprising. Violence is foregrounded: "SCUM will not picket, demonstrate, march, or strike.... Such tactics are for nice, genteel ladies. If SCUM ever strikes ... it will be in the dark with a six-inch blade" (581). Unlike Fanon, however, she advocates only rational violence: "Both destruction and killing will be selective and discriminate, SCUM is against half-crazed, indiscriminate riots, with no clear objective in mind..." (582).

By the mid to late 1970 s, the lyrical manifesto refines the rhetorical manifesto, articulating what Lorde calls the "difference between poetry and rhetoric" with the power to mobilize anger along a creative and/or cultural cutting edge beyond mere incitement to resistance, reaction, and ressentiment. Perhaps the most exciting collection of manifesto poems to emerge in this period with Black Unicorn is Olga Broumas's Beginning With $O$ (1977). Like Lorde's "Women of Dan," Broumas's "Artemis" declares a poetico-political "code of arms":

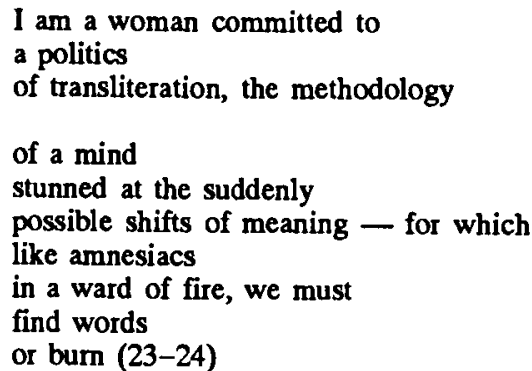

Another poem, entitled point-blank "the knife and the bread," articulates Broumas's experience of the Turkish invasion of Cyprus, of which she notes that "true to most warfare other than nuclear, there was one war between the two countries and another against the women of Cyprus." Against men's cul- 
ture of militancy, it manifests woman's avant-garde determination to "give the poem authority to kill" (Hammond 35):

i tell you violence

perseveres..

i am sick with knives, knives

slashing breasts away, hand-held

knives cutting wounds to be raped

by cocks, thick blunt knives

sheathing blood, knives

paring cheeks away

knives in the belly... 0

i slice the bread

in the kitchen, $i$ hold the knife

steady against the grain...

...how long

can i keep the knife

in its place ${ }^{40}$

Broumas writes from not only a brutal war experience but also an avant-garde tradition initiated by Greek women poet-guerrillas writing and fighting for the resistance during World War II and the Junta. Contemporary feminist avant-gardes might connect with these traditions - though it seems like quite a paradoxical thing to do given that avant-gardes are, by definition, forward, not backward looking. ${ }^{41}$ However, given its struggle with massive backlash, and its failure to attain equally massive popularity, feminism has trouble forging continuities from decade to decade, movement to movement, and every reason to gather forces that have been diffused across the double diachronic and synchronic axes of history.

Conversely, there is no doubt that a feminist avant-garde has had the power to mobilize feminist culture. The widespread effects of "consciousnessraising" in the U.S. spurred on by radical American and French avant-gardes are widely known, ${ }^{42}$ and Teresa de Lauretis has recently brought the cultural efficacy of the avant-garde manifesto in Italian feminism to our historical and theoretical attention. ${ }^{43}$
However, the avant-garde chapter in the history of twentieth-century feminism has yet to be written. When it is, it will have to respond to Julia Kristeva's counter-manifesto, "Women's Time," which the simultaneous arrival of postfeminism and postmodernism in the diffusive ' $80 \mathrm{~s}$. In this essay, Kristeva launches an attack on radical feminism and on feminist writing, ${ }^{44}$ at the same time as she defends Hegel and Lacan for their "true" formulation of the "implacable violence which constitutes any symbolic contract" (203). Equating lesbian motherhood with terrorism, 45 and radical feminism with goddess-worshipping cults which, if universalized, would set ablaze a holocaust too horrific to imagine (205), Kristeva denies outright the possibility of a feminist avant-garde, of any discourse or symbolic endeavour, that might break with or attempt to overthrow the patriarchal social-symbolic order. After relegating feminism to the cultural imaginary, where it is strictly limited to phantasmatic production, she then accuses feminism of wishing to materialize this production in reality. Her discourse betrays a paranoiac logic she so vigorously attributes to feminism; more disturbingly, however, it denies women any collective and/or effective expression against violence systematically imposed on them:

But when a subject is too brutally excluded from this socio-symbolic stratum; when, for e.g., a woman feels her affective life as a woman of her condition as a social being too brutally ignored by existing discourse or power (from her family to social institutions); she may, by counter-investing the violence she has endured, make of herself a "possessed" agent of this violence in order to combat what was experienced as frustration - with arms which may seem disproportional, but which are not so in comparison with the subjective or narcissistic suffering from which they originate.... It must be pointed out, however, that since the dawn of feminism, and certainly before, the political activity of exceptional women, and this in a certain sense of liberated women, has taken the form of murder, conspiracy and crime. (203-4)

For Kristeva, the future of feminism lies with an avant-garde that will lead it beyond "the idea of 
difference," forging a break from "its belief in Woman, Her power, Her writing, so as to channel this demand for difference into each and every element of the female whole, and finally, to bring out the singularity of each woman, and beyond this, her multiplicities, her plural languages, beyond the horizon, beyond sight, beyond faith itself" (208).

Such a feminist écriture, however, is actually demobilizing and diffusive: instead of advocating a cultural front, she envisions the disintegration of collective action, a devolution into liberal pluralism with every woman writing her difference, her language, "beyond sight" of the culture of violence hurled against her. Concluding her counter-manifesto with rhetorical questions concerning feminist counter-violence, "a factor for ultimate mobilization? Or a factor for analysis?" (208), Kristeva proposes to replace collective action (reductively construed as unilateral regression to identity politics) for a feminine unwriting of any and all isms: "imaginary support in a technocratic era where all narcissism is frustrated? Or instruments fitted to these times in which cosmos, atoms and cells our true contemporaries - call for the constitution of a fluid and free subjectivity?" (208). With this cry of retreat, Kristeva ushers in the '80s, whose postmodern death-drive is aimed at shattering pretensions of solidarity by a white, middle-class vanguard in the name of enhanced racial, sexual, and technological diversification. By the end of this decade, however, we witness a return to a call for violence and terrorism.

\section{Today's "Angry Women": A Gathering of Forces in the '90s}

A very recent publication coming out of San Francisco, where new and old avant-gardes seem to grow and die and coincide, heralds the emergence of Juno and Vale's Angry Women (1991), including, among others, such daring critics and artists as Lydia Lunch, Kathy Acker, bell hooks, Avital Ronell, and Diamanda Galás. Many of these women choose centre stage in the performance industries, video and film, television, $\mathrm{CD}$, live stage, and, like the historical avant-garde, are intent upon provoking violence in their audience, with especial de- termination to arouse the women. Their gigs range from "ivory tower terroris[m] (Ronell 127) launched in the classroom or conference hall (130) to microphonic improvisations of "Wild Women with Steak Knives" in live theatre (Galás 8).

Breaking through the fog of the postmodern ' $80 \mathrm{~s}$, these women reengage the strategies of radical feminists of the $70 \mathrm{~s}^{46}$ and the historical avantgarde, notably Artaud's theatre of cruelty, ${ }^{47}$ with the confidence of two decades of feminist activism and theory, and a violence capable of overwhelming and overturning the atmosphere of backlash. They present themselves as feminist guerrillas in a war against women which they wage on their own terms. "I'm rallying the troops," Lydia Lunch declares. "That's my job. Everyone should assume a position in the ranks of this army, because it is war, and that's it" (115). To make her meaning clear, Diamanda Galás goes "beyond" the verbal tactics of manifesto art, training her vocal cords "to yield an ubervoice," which delivers "an immediate extroversion of sound," with "a pointed, focussed message - like a gun" (8). Her point? That women's attitudes must be changed dramatically:

\footnotetext{
I'm disgusted with the ideal of women making themselves invisible as they go down the street - that has to be turned around. The attitude is the first thing - whether you back it up with your physical self-defense or a gun is your option, but the attitude needs to be there. Nowadays we're not just talking about being hassled by one or two men at a time, we're talking about packs of men. (8)
}

"Angry women" also vocalize their determination to empower women with an affirmative, buoyantly aggressive art. In response to the question, "what's 'wrong' with feminism today?" Ronell answers that:

it's dependent on what man does. Feminism has a parasitical, secondary territoriality ... subject to reactive, mimetic and regressive posturings. So the problem is, how can you free yourself? How can you not be reactive to what already exists as powerful and dominating? How can you avoid a ressentimental politics? Is it possible to have a feminism that is joyous, relentless, outrageous, libidinally charged - (127). 
And in this country? Now that feminism has put the nation on alert against violence against women, it needs more than ever to rally cultural forces behind a thoroughly aggressive avant-garde. Perhaps, in Canada, where women are far more reticent to arm themselves with Lady Smith revolvers than their American counterparts, we have a greater chance of mobilizing our suppressed death-drive into a collective cultural front. To date, however, no such front exists and our most reliable institutions are failing us.

Margaret Atwood's backward glance at previous decades of the feminist movement in caustic, fictive memoir is hardly the stuff of revolution: Cat's Eye (1988) will not do, especially not after her dystopian Handmaid's Tale (1985) and her amnesty novel, Bodily Harm (1981). In any case, Atwood has been appropriated by popular culture and, like Violent Femmes, is more likely to denote men's rock groups than feminist avant-gardes. ${ }^{48}$ For its part, although it has given itself more than enough cause to set the torch to our culture of antiwoman pomography after widely screening its provocative Not A Love Story (1981), the National Film Board's Studio $\mathrm{D}^{49}$ has produced nothing comparable to Lizzie Borden's Born in Flames (1977) and Monika Treut's The Virgin Machine (1987). Instead, it has attempted to lighten the scene with a new documentary, Wisecracks (1992), about female (explicitly not feminist) stand-up comics. Neither this nor Five Feminist Minutes $(1991)^{50}$ can evoke the affect needed to mobilize war against centuries-old cultivation of violence against women. ${ }^{51}$ We urgently need a rallying new instalment of Firewords in the empowering wake of avant-garde poets Louky Bersianik, Jouvette Marchessault, and perhaps our most effective guérillère, Nicole Brossard. ${ }^{52}$ We need more activist productions, more Sisters in the Struggle (1991) to multiply and advance our forces against men's culture of violence. "In a ward [read nation] of fire, we must/ find words/ or bum."
1. "Feminists, who've lobbied for years for greater attention to this issue, say it's about time. Other social issues got attention, but none inspired such consistent activism and discussion, such constant media coverage and such strong governmental response. Pollster John Wright, senior vicepresident of the Angus Reid group, a national marketing research and polling firm, says feminists successfully pushed the issue.... 'It has taken 30 years for the issues of women to come to the fore ... but the time is right for it because the country feels it is right"' (Davis-Barron 1991).

2. Feminists have also brought violence against women into international news, with headline issues concerning the massive abduction and exploitation of girls and women by sex trade operators in the Philippines; gynocide in China where an estimated 1,000,000 girls and women are suspected "missing" due to female infanticide, malnutrition and severe neglect; the recently exposed abduction and forced prostitution of an estimated 100,000 to 200,000 women, mostly Korean, by Japan's imperial army between 1931 and 1945 (Reuter, B8).

3. "There is something terrifying," Sorel notes approvingly of workers' strikes, "which will appear more and more terrifying as violence takes a greater place in the mind of the proletariat. But in undertaking a serious, formidable and sublime work, Socialists raise themselves above our frivo- lous society and make themselves worthy of pointing out new roads to the world" (Sorel 275).

4. Fanon defends violence enacted by natives in colonial regimes since "it constitutes their only work, invests their characters with positive and creative qualities," and "binds them together as 2 whole." The violence of decolonization/ liberation "introduces into each man's consciousness the ideas of a common cause, of a national destiny, and of a collective history." Such violence "is cleansing. It frees the native from his inferiority complex and from his despair and inaction; it makes him fearless and restores his selfrespect." Furthermore, it is demystifying: "illuminated by violence, the consciousness of the people rebels against pacification. From now on the demagogues, the opportunists, the magicians have a difficult task. The action which has thrown them into a hand-to-hand struggle confers upon the masses a voracious taste for the concrete. The attempt at mystification becomes, in the long run, practically impossiblen (93-95).

5. The "Strategies for Power" workshop was organized by Dr. Norma Walmsley, Chairperson of the Subcommittee on the Status of Women of the Canadian Commission for UNESCO. There were twenty-six delegates, representing the UK, France, Italy, Norway, West Germany, Canada, and two intemational agencies. Participants were politicians, 
academics, administrators, professionals and leaders of women's organizations, including Judy Erola, federal minister responsible for the Status of Women, Flora Macdonald, former minister of external affairs, Lady Trixie Gardner, a member of the House of Lords, and Eva Rath, founder of the Frauenpartie (Gillett 201).

6. In "Violence, Fear and Feminism: Fragments of a Reflection," Simone Landry argues that, regardless of violent anti-feminist backlash and despite the cultural double standard which condones violence for boys while teaching girls "to repress it and to turn it inward against themselves," feminist non-violent resistance "must continue in full force" (119-24). Paula Sypnowich observes in "An Incitement to Violence" that, although feminism has made violence against women more intolerable, "every aspect of popular culture implicitly encourages it"; spurring the liberal conscience is not enough but counter-violence would be going too far (128-31). In "The Vicious Circle of Violence," Gloria Escomel condemns violence outright, arguing that to see its absolute abolition, women's liberation must abandon male destructiveness and imitate feminine repression (131-35).

7. As Ti-Grace Atkinson observes: "It has been necessary to program women's psychic structure to nonresistance on their own behalf - for obvious reasons - they make up over half of the population of the world" (51). Elsewhere, she despairs of arousing an audience of academic feminists to violence: "I suspect I am making a mistake. Perhaps I am trying to ingratiate myself with you by considering this subject in a serious manner. In fact, I truly believe the discussion of violence as a tactic for the Women's Movement is, at best, absurd.... I think that the increasing discussion of violence, as a concept or tactic relevant for us, is a case of 'militancy of the mouth"' (202).

8. McCracken offers three weak "counterarguments" to women's violence against violence against women, the first being "the strong contention of some feminist groups that violence is a peculiarly male way of engaging with the world, that it is simply not an important or characteristic part of the female repertoire," which he dismisses with the claim, also feminist, that such categorical thinking is outdated and "merely reconstructs the ghetto." The second counterargument is that violence by women would be met with still more violence by men, which he rejects as hackneyed, observing that it "is always used against the use of violence by subordinate groups, and ... is the argument virtually every one of the subordinate groups ignores." The third counterargument is "the one from the status quo," namely that "women do not resort to violence in the present, ... so they will not resort to violence in the future," which he negates by asserting that given female stereotyping is "being challenged and repudiated. The inclination to answer violence with violence may well become a new and quite ordinary feature of femaleness" (A16).

9. The violent death of Jane Hurshman Corkum on 22 February 1992 might present stronger evidence of terrorizing backlash. Corkum, acquitted of first-degree murder in 1984 after shooting and killing her severely abusive husband, was later herself found shot to death. While police suspect suicide, friends and women's groups suspect murder, recalling that before she died she received threatening letters and phone calls telling her to stop speaking out on the abuse of women. After her probation ended in 1986, Corkum began a public campaign against violence against women, which she continued until the last week of her life, when she had been scheduled to speak on wife battery before the Halifax session of the Federal Panel on Violence Against Women and at a women's agency in Bridgewater, not far from her former Bangs Falls home (Jones 00).

10. De Lauretis's project of subversive imaging is based primarily upon Charles Peirce's notion of "semiosis" and, in particular, upon the epistemological action of what he calls "the interpretant." Elaborating Peirce's philosophical pragmatism and applying it to avant-garde film studies, de Lauretis identifies the interaction between spectating subject and the screen as the prime arena for habit-changing interpretative activity or subversive semiosis. With the advent of feminist reading practices, she projects a semiosis that is powerful enough to resist the naturalization of patriarchal codes of desire. Furthermore, given women's entry into the film industry as avant-garde film producers, she foresees transforming codification of desire into something quite new: 2 signifying practice that accommodates women's contradictory experience in discourse as overrepresented object and under-represented subject. See Alice Doesn't: Feminism/Semiotics/Cinema (1984).

11. The avant-gardist "places himself in an explicit social context and calls the attention of the writer and audience to the inherent social dynamics of their culture, whether those dynamics be represented by other visionaries, scientists, political activists, or even apparently abstract and impersonal forces with which the writer identifies" (Russell 16).

12. "Pouvoirs et contre-pouvoirs: la place des femmes dans la vie politique" was held at the Université du Québec à Montréal (UQAM), 4-8 June, 1985, and was supported by the Secretary of State Canada (Promotion of Women Programme), the Dean of Graduate Studies and Research at UQAM, the Social Science and Humanities Research Council of Canada (SSHRCC), and a host of political and educational administrators (Cohen 13).

13. Sponsored by MATCH International, the Women in Development Directorate and the Canadian International Development Agency, 6-8 March, 1992, to mark International Women's Day. "Speakers from India, Brazil, Dominican Republic, the U.S., and Canada told an audience of about 100 at the Ottawa Congress Centre that victimization of women world-wide can only be stopped by united action" (Canadian Press 1992a, A3).

14. Yolande Cohen introduces her edition of the "Pouvoirs et contre-pouvoirs" proceedings, with the statement that the time has come for advancing on both utopian and liberation fronts: "One thing is for certain: the movement has profoundly transformed social and political reality. Feminism is now groping for the solutions it will have to advocate in the future. In this context, the political universe must expand to include new modes of social intervention. There is plenty of room on the horizon to conceive of utopias, as well as to develop strategies for the liberation of women, a process timidly begun by emancipatory feminism" (25). 
15. Feminism might aim its provocative deconstructive analysis at the language of backlash. In "Murderous Fallout: Post-Lépine Rhethoric [sic]," Catherine Nelson-McDermott pierces the veil of masculist reaction in letters to the editor written after the publication of feminist readings of the Montreal massacre. She points to a battery of fallacies (ad feminam; begging the question; post hoc, ergo propter hoc) which turn feminism's protest against men's violence against feminism itself. As she eloquently observes: "not only are the terms of the feminist argument perverted to such an extent they are no longer recognizable, the problem of violence against women disappears into a rhetorical 'fog' thrown up around the belief female and feminist theorizing is not a response to socially perpetuated violence but its cause" (126). The most insidious of these tactics, post hoc, ergo propter hoc, "both ignores historical realities (pervasive violence against women was a cultural reality before there were feminists) and conceals an underlying threat intended to silence feminists through fear" (126). The circular subtext of this reaction is viciously clear: if feminists continue to speak out, men will be driven to follow Marc Lepine's example. Such coercive and pervasive discourse, she concludes, assaults women no less violently than direct bodily harm (127).

16. As Irigaray explains in detail: they must expose the "domination of the philosophical logos" from its power to "eradicate the difference between the sexes in systems that are self-representative of a 'masculine subject"' (1985a, 123); they must interrogate "the conditions under which systematicity itself is possible: what the coherence of the discursive utterance conceals of the conditions under which it is produced ... without overlooking the mirror, most often hidden, that allows the logos, the subject, to reduplicate itself, to reflect itself by itself" (123); they must "listen (psycho)analytically to its procedures of repression" (123-24); they must examine "the operation of the 'grammar' of each figure of discourse, its syntactic laws or requirements, its imaginary configurations, its metaphoric networks, and also, of course, what it does not articulate at the level of utterances: its silences" (124).

17. Irigaray makes perfectly clear that this textual work is political work. For one thing, philosophical reduction is politically determined and politically oppressive: "Every operation on and in philosophical language, by virtue of the very nature of that discourse - which is essentially political - possesses implications, that, no matter how mediate they may be, are nonetheless politically determined" (1985a, 128). For another, women's entry and intervention into this discursive order is potentially revolutionary: "the first question to ask is therefore the following: how can women analyse their own exploitation, inscribe their own demands, within an order prescribed by the masculine? Is a women's politics possible within that order? What transformation in the political process itself does it require?" (128)

18. Irigaray astutely points out the violence against women in both traditional and deconstructive philosophical discourse. As Margaret Whitford explains: "The deconstruction of identity continues to leave women in a state of fragmenta- tion and dissemination which reproduces and perpetuates the patriarchal violence that separates women. Although both Derrida and Irigaray point to the violence of patriarchal metaphysics, for Irigaray, deconstruction seen from women's point of view has not been able to imagine any way of addressing its own theoretical death drive, its own nihilism" (121).

19. Whitford makes this excellent qualification: "Phallomorphic identity has become rigid and destructive to men and women alike; but its deconstruction may be equally destructive if it does not allow mobility to women. However we conceive identity, it must be thought of in terms of the female imaginary, an imaginary that will bind or attach the scraps and debris together into something which gives women a 'home' but does not prevent their mobility, their becoming, and their growth. Identity is feared - rightly because of its immobilizing and blocking tendencies; but without it there is paralysis" ${ }^{n}$ (138).

20. Ideally, women's reconstruction of community identity would avoid reproducing men's violent formations. "There is a plea here not to imitate the sacrificial violence of men by making other women scapegoats to ensure unanimity within communities of women, but to find other ways of resolving conflicts. And it is essential that rites be public, social, symbolic - not private, individual, and hidden. Without symbolic mediation, violence always threatens" (Whitford 146).

21. The title of this paper, "Violence Against Violence Against Women," was deliberately chosen against the more commonplace "Women Against Violence Against Women," to indicate an emphasis on strategy rather than on identity.

22. Continues Lorde: "In touch with the erotic, I become less willing to accept powerlessness, or those other supplied states of being which are not native to me, such as resignation, despair, self-effacement, depression, self-denial" (1984, 58).

23. This phrase is from Adrienne Rich, "The Buming Paper Instead of Children" (117).

24. "The women say that even without the feminaries they can recall the time when, as was typical of them, they made war. They say that all they need to do is to invent terms that describe themselves without conventional references to herbals or bestiaries. They say that what they must stress above all is their strength and courage" (Wittig 53).

25. "The women say, you are really a slave if ever there was one. Men have made what differentiates them from you the sign of domination and possession. They say, you will never be numerous enough to spit on their phallus, you will never be sufficiently determined to stop speaking their language, to bum their currency their effigies their works of art their symbols. They say, men have foreseen everything, they have christened your revolt in advance a slave revolt, a revolt against nature, they call it revolt when you want to appropriate what is theirs, the phallus. The women say, I refuse henceforward to speak this language, I refuse to mumble after them the words lack of penis lack of money lack of insignia lack of name. I refuse to pronounce the names of possession and nonpossession. They say, If I take over the world, let it be to dispossess myself of it 
immediately, let it be to forge new links between myself and the world" (Wittig 106-7).

26. "Females who look like women when they are dead" recalls Sylvia Plath's "Lady Lazarus": "Dying/ Is an art, like everything else./I do it exceptionally well./ I do it so it feels like hell./ I do it so it feels real./ I guess you could say I've a call./...Beware/ Beware./ Out of the 2sh/ I rise with my red hair/ And I eat men like air" (245-47). Both Adrienne Rich and Hélène Cixous rouse readers with an image of women awakening from the dead, as does Audre Lorde in "The Women of Dan Dance With Swords in Their Hands to Mark the Time When They Were Warriors": "I come as a woman/ dark and open/ some times I fall like night/ softly/ and terrible/ only when I must die/ in order to rise again" $(1978,14)$.

27. "Without this confrontation and a detailed understanding of what his [man's] battle strategy has been that has kept us so successfully pinned down, the Women's Movement is worse than useless," Alkinson argues. "It invites backlash from men and no progress from women" (47).

28. "Their favorite weapons are portable. They consist of rocket-launchers which they carry on the shoulder. The shoulder serves as a support for firing. It is possible to run and change position extremely quickly without loss of fire-power. There is every kind of rifle.... The manoeuvres are raids ambushes surprise attacks followed by a rapid retreat" (Wittig 1971, 95).

29. "The women say that they [the Military men] have a concem for strategy and tactics. They say that the massive armies that comprise divisions corps regiments sections companies are ineffectual. Their exercises consist of manoeuvres marches guards patrols. These afford no real practice for combat. They say that in these armies the handling of weapons is not taught efficiently. They say that such armies are institutions. One refers to their barracks their posts their garrisons.... They say with this concept of war weapons are difficult to deploy, effectives cannot adapt to every situation..." (Wittig 1971, 94).

30. "This is why," Fanon insists, "any study of the colonial world should take into consideration the phenomena of the dance and of possession" (57).

31. As dramatized in the rest of Lorde's poem: "and one day I will take my teenage plug/ and connect it to the nearest socket/ raping an 85-year-old white woman/ who is somebody's mother/ and as I beat her senseless and set a torch to her bed/ a greek/ chorus will be singing in $3 / 4$ time/ 'Poor thing. She never hurt a soul. What beasts they are"' ("Power" 109).

32. Perloff also observes that contemporary cross-genre productions though lacking the intention to be politically or culturally mobilizing have their origins in this manifesto art. "The Tzara manifesto is often indistinguishable from a prose poem; its coterie address, its complex network of concrete but ambivalent images, and its elaborate word play and structuring look ahead to André Breton's first Surrealist manifesto of 1924 and, beyond Breton, to many of our own exemplars of conceptual art - texts no longer claiming to be manifestos and to move society to action, but occupying a similar space between lyric and narrative, or lyric and theatre, or lyric and political statement" (11415).
33. Though Wittig's Les Guérillères leaves room for critical rumination, it is clearly indebted to the manifesto art of historical avant-garde, especially that of the futurists - as we can see in the following passage: "The women say that, with the world full of noise, they see themselves as already in possession of the industrial complexes. They are in the factories aerodromes radio stations. They have control of communications. They have taken possession of aeronautical electronic ballistic data-processing factories. They are in the foundries tall fumaces navy yards arsenals refineries distilleries. They have taken possession of pumps presses levers rolling-mills winches pullies cranes turbines pneumatic drills arcs blow-lamps. They say that they envisage themselves acting with strength and happiness. They say that they hear themselves shout and sing, Let the sun shine/ the world is ours" (97).

34. Continues Loy:

Professional and commercial careers are opening up for you. Is that all you want? If you honestly desire to find your level without prejudice, be BRAVE and deny at the out-set that pathetic clap-trap warcry, "Woman is the equal of man."

She is not.

Leave off looking to men to find out what you are not. Seek within yourselves what you are. As conditions are at present constituted you have the choice between Parasitism, Prostitution, or Negation.

Men and women are enemies, with the enmity of the exploited for the parasite, the parasite for the exploited - at present they are at the mercy of the advantage that each can take of the other's sexual dependence. (269)

35. Consider the violent rhetoric of H.D.'s "Sheltered Garden" (1916), which attacks the traditional patriarchal convention of figuring erotic femininity as domesticated flora: "I have had enough.../ For this beauty,/ beauty without strengthJ chokes out life./I want wind to break/ scatter these pinkstalks, J snap off their spiced heads, / fling them about with dead leaves $-/$ spread the paths with twigs,$/$ limbs broken off $/$ trail great pine branches, $/$ hurled from some far wood/ right across the/ melon-patch,/ break pear and quince - / leave half-trees, tom, twisted/ but showing the fight was valiant/ $O$ to blot out this garden/ to forget, to find a new beauty/ in some terrible/ wind tortured place" (5-6).

36. I refer particularly to Plath's most famous and most disturbing poem, "Daddy" (1962), which declares the poet's violent break with the patriarchal family romance. The poem ends with these lines: "If I've killed one man, I've killed two The vampire who said he was you/ And drank my blood for a year,/ Seven years, if you want to know./ Daddy, you can lie back now./ There's a stake in your fat black heart And the villagers never liked you./ They are dancing and stamping on you./ They always knew it was you./ Daddy, daddy, you bastard, I'm through" (224).

37. One of the few women "Beats," Diane Di Prima occupied an extremely difficult position in an avant-garde whose primary strategy was to declare a war of male virility against establishment anti-sexuality. Her "pornographic" writing might be read in this context, as well as her revo- 
lutionary verse. I quote from "Revolutionary Letter \#32": "...the acts of song, the acts of power, not lost/ to us these many years, not killing a few white men will bring/ back power, not killing all the white men, but killing/ the white man in each of us, killing the desire..." (210).

38. Both of these anthologies adhere as much as possible to manifesto form by printing the most provocative passages of longer texts and by collecting them under equally provocative headings.

39. "What distinguishes Cixous's manifesto from its forerunners (Marinetti's Futurist manifestos, Tzara's Dada manifestos, Breton's Surrealist manifestos)," Suleiman contends, "is that Cixous explicitly equates the radically new, subversive text with the 'feminine text"' (17).

40. In response to Hammond's request that she "recount the details surrounding her writing" this poem, Broumas recalls: "Greece, summer of 1974 , the Turkish invasion of Cyprus.... The soldiers were being very, very brutal to the women of Cyprus. Personally, it had been a painful summer.... A woman who ran the grocery store down the street from my parents had sent her two daughters to spend the summer with her mother. All three were killed, brutally. I came back from that summer and tried to write, found myself in a poem literally going crazy. You can see that in the beginning, hiding in metaphors and images, saying ' $I$ can't handle this.' It was a classic Plathian stance that I'd been taught how to do. So I worked on it for three and a half months, four to five hours daily, until I got to the point where I could say 'how long can I keep the knife/ in its place?' and mean it" (Hammond 35).

41. Andreas Huyssen argues that since the 70 s cultural practices "actually point to the vital need not to abandon history and the past to tradition-mongering neoconservatives bent on reestablishing the norms of earlier industrial capitalism: discipline, authority, the work ethic, and the traditional family." But he also argues that however much this need "manifests itself in the concern with cultural formations not dominated by logocentric and technocratic thought, in the decentering of traditional notions of identity, in the search for women's history," this new search for tradition inevitably points to "exhaustion of the tradition of the avant-garde" (172). The search for a women's avant-garde tradition, I argue, poses a paradox, not a termination.

42. Among the French feminists, Monique Wittig has perhaps had the greatest effect on feminist culture in the U.S., especially in mobilizing the lesbian counter-culture of "fighting back" (Spinster 310).

43. In her introduction to Sexual Difference: $A$ Theory of Social-Symbolic Practice, de Lauretis documents the history and theory of manifesto action on Italian feminism since the 1960s. She traces the effectiveness of the Demau (acronym for Demystification of Patriarchal Authoritarianism) manifesto in 1966, calling for a reversal in the Marxist formulation of "the woman question," before proceeding to the widespread reception of Carla Lonzi's celebrated manifesto, Spitiamo su Hegel [Let's Spit on Hegel], in 1970 and the autoconscienza movements which it spurred on in the 70 s, to the formulation of "the sexual difference theory" in a manifesto entitled "Piú donne che womini [More women than men] by the Milan Bookstore collective in 1983 and its "unprecedented influence on progressive political thought, as represented by the second largest party of Italy, the PCI [the Italian Communist Party] (5-14). She also traces the formulation of "lesbofemminismo" manifestos during this period (1990, 14).

44. "Thanks to the feminist label, does one not sell numerous works whose nalve whining or market-place romanticism find the pen of many a female writer being devoted to phantasmic attacks against Language and Sign, as the ultimate supports of phallocratic power, in the name of a semi-aphonal corporality whose truth can only be found in that which is 'gestural' or 'tonal?" (Kristeva 207).

45. "In the refusal of the paternal function by lesbian and single mothers can be seen one of the most violent forms taken by the rejection of the symbolic ... as well as one of the most fervent divinizations of maternal power - all of which cannot help but trouble an entire legal and moral order, without proposing an altemative to it" (Kristeva 205).

46. Lydia Lunch recalls Valerie Solanis: "I'd like to see a women's army storm into the White House with Uzis and shotguns and eliminate at least half the population who work in politics. They're killing you slowly - what's the alternative? Kill them quickly now - before they kill everything else, okay? (Lunch 115).

47. Like Broumas, Galas notes her avant-garde in Greek women's cultural traditions - in particular, the moirologi of the Maniot women whose practice of mourning was doubly capable of prompting sorrow and mobilizing anger over the killing of Greek nationals. "Now the women pull out their hair and scream as an incantation to the dead. Because the women would speak directly to the dead, they were seen as a threat to the authority of the patriarchal society and were labeled 'witches.' More importantly, the women would speak for the dead, expressing the feelings of the dead. In 'Were You a Witness?' I say: 'We who have gone before do not rest in peace/ We who have died shall never rest in peace/ Remember me, I am unburied/ I am screaming in the bloody surfaces of hell ... There is no rest until the fighting's done $(11-12)$.

48. I refer to the recent hit single "Margaret Atwood."

49. Studio D is a part of the National Film Board of Canada's English Program Branch and was set up as the first publicly funded feminist production unit of its kind in the world. Its objectives are: "to bring women's perspectives to the films we produce and to provide opportunities for Canadian women to move into the motion-picture occupations traditionally dominated by men ${ }^{n}$ (National Film Board of Canada 3).

50. In celebration of its 15 th anniversary in 1989, Studio D compiled a series of sixteen five-minute "snapshots of the world from a feminist perspective" by independent women filmmakers, under the title Five Feminist Minutes (National Film Board of Canada 5).

51. Dionne Brand and Ginny Stikeman's recent film, Sisters in the Struggle (1991) is one of the few activist films listed in the N.F.B. catalogue. A film documentary rather than an 
avant-garde production, it looks at "contemporary Black women activists, of varying ages and backgrounds, involved in the movements against racism and sexism in Canada." However, it advances the notion of a feminist avant-garde by aligning activists engaged in many movements - "in the labour movement, in community organizing, in electoral politics, in anti-poverty organizing and in feminist organizing" - and by linking these struggles "with the ongoing battle against pervasive racism and systemic violence against women and people of colour in Canada (National Film Board of Canada 3).

52. Studio D's production of Les Terribles Vivantes [Firewords], directed by Dorothy Todd Henaut, comes in three parts, devoted to the politics and poetics of Quebec feminist writers Louky Bersianik, Jouvette Marchessault and Nicole Brossard.

\section{REFERENCES}

Artaud, Antonin. The Theatre and Its Double. Trans. Victor Corti. 1964; London: John Calder, 1970.

Atkinson, Ti-Grace. Amazon Odyssey. New York: Links Books, 1974.

Berman, Russell A Modern Culture and Critical Theory. Madison: $U$ of Wisconsin P, 1989.

Bourdieu, Pierre. In Other Words: Essays Towards a Reflexive Sociology. Trans. Matthew Adamson. Stanford: Stanford UP, 1990.

Broumas, Olga. Beginning With $O$. New Haven: Yale UP, 1977.

Bürger, Peter. Theory of the Avant-Garde. Trans. Michael Shaw. 1980; Minneapolis: U of Minnesota P, 1984.

Canadian Press. "Mentality of Violence Must Change - Panel." Edmonton Journal (16 Feb. 1992), C2

Canadian Press. "International Women's Conference Hears Rallying Cry Against Violence." Edmonton Journal (8 Mar. 1992), A3.

Chesler, Phyllis. Women and Madness. New York: Harcourt Brace Jovanovich, 1972.

Cixous, Hélène. "The Laugh of the Medusa." In Marks and de Courtrivron, New French Feminisms. 245-64.

Cohen, Yolande. Ed. Women and Counter Power. Montreal: Black Rose, 1989.

Davis-Barron, Sherri [Ottawa Citizen]. "Men's Violence Against Women Found Spotlight: Women's Issues in 1991." Edmonton Journal (29 Dec. 1991), A3.

de Lauretis, Teresa. Sexual Difference: $A$ Theory of SacialSymbolic Practice. Bloomington: Indiana UP, 1990.

de Lauretis, Teresa. Alice Doesn't: Feminism/Semiotics/Cinema. London: Macmillan, 1984.

Deleuze, Gilles and Félix Guattari. A Thousand Plateaus: Capitalism and Schizophrenia. Trans. Brian Massumi. 1980; Minneapolis: U of Minnesota P, 1987.

Dickinson, Emily. The Complete Poems of Emily Dickinson. Ed. Thomas H. Johnson. Boston: Little, Brown, and Co., 1960.

Di Prima, Diane. Selected Poems: 1956-1975. Plainfield, VT: North Atlantic Books, 1975.

Doolittle, Hilda [H.D.] Selected Poems. Ed. Louis Martz. New York: New Directions P, 1988

Dworkin, Andrea. 1991a. Address. "Women in a Violent Society" Conference. Banff, AB, 9-12 May., 6-7.

Dworkin, Andrea. 1991b. "Andrea Dworkin Speaks." The Womanist 2.4: 6-8.

Escomel, Gloria. "The Vicious Circle of Violence." In Malette and Chalouh, The Montreal Massacre. 131-35.
Fanon, Frantz. "Conceming Violence." In The Wretched of the Earth. Trans. Constance Farrington. 1961; New York: Grove P, 1963. 35-106.

Fiedler, Leslie. "The Death of the Avant-Garde." In The Collected Essays of Leslie Fiedler. Vol. 2. New York: Stein and Day, 1971. 454-60.

Foucault, Michel. Language, Counter-Memory, Practice. Ed. Donald F. Bouchard. Ithaca: Cornell UP, 1977.

Galas, Diamanda. [Interview with Andrea Juno]. In Juno and Vale, Angry Women. 6-22.

Georges-Abeyic, Daniel. "Women as Terrorists." Perspectives on Terrorism. Eds. Lawrence Zelic Freedman and Yonah Alexander. Wilmington, DE: Scholarly Resources, 1983. 71-84.

Gillett, Margaret. "Strategies for Power." Women and Counter Power. Ed. Yolande Cohen. 1989. 200-9.

Hammond, Karla. "An Interview with Olga Broumas." Northwest Review 18.3 (1980): 33-44.

Hoffman, Piotr. Violence in Modern Philosophy. Chicago: $\mathrm{U}$ of Chicago P, 1989.

Howe, Susan. My Emily Dickinson. Berkeley: North Atlantic Books, 1985.

Huyssen, Andreas. After the Great Divide: Modernism, Mass Culture, Postmodernism. Bloomington: Indiana UP, 1986.

Irigaray, Luce. This Sex Which Is Not One. Trans. Catherine Porter. 1977; Ithaca: Comell UP, 1985a. 68-85.

Irigaray, Luce. Speculuon of the Other Woman Trans. Gillian C. Gill. 1974; Ithac2: Comell UP, 1985b. 53-55.

Jones, Deborah. "A Violent End to a Life of Abuse." The Globe and Mail [Toronto], (2 Mar. 1992), A4.

Juno, Andrea and V. Vale. Eds. Angry Women. San Francisco: $\mathrm{Re} /$ Search Publications, 1991.

Kristeva, Julia. "Women's Time." The Kristeva Reader. Ed. Toril Moi. Oxford: Blackwell, 1986. 187-213.

Landry, Simone. "Violence, Fear and Feminism: Fragments of a Reflection." In Malette and Chalouh, The Montreal Massacre. 119-24.

Lorde, Audre. "Uses of the Erotic: The Erotic as Power." In Sister Outsider: Essays and Speeches. Freedom, CA: The Crossing P, 1984. 53-59.

Lorde, Audre. The Black Unicorn. New York: Norton, 1978.

Loy, Mina. The Last Lunar Baedeker. Manchester: Carcanet P, 1982.

Lunch, Lydia. [Interview with Andrea Juno]. In Juno and Vale, Angry Women. 105-17. 
McCracken, Grant. "A Call to Arms for Women?" The Globe and Mail [Toronto], (16 Dec. 1991), A16.

Malette, Louise and Marie Chalouh. Eds. The Montreal Massacre. Trans. Marlene Wildeman. 1990; Charlottetown: Gynergy Books, 1991.

Marks, Elaine and Isabelle de Courtrivron. Eds. New French Feminisms. Brighton: Harvester, 1980.

Morgan, Robin. Ed. Sisterhood Is Powerful: An Anthology of Writings form the Women's Liberation Movement. New York: Vintage, 1970.

Nadasen, Pam. "United We Stand." The Women's Review of Books 9.5 (Feb 1992): 31.

National Film Board of Canada. Beyond the Image. Montreal, 1991.

Nelson-McDermott, Catherine. "Murderous Fallout: Post-Lepine Rhethoric [sic]." Atlantis 17.1 (1991): 124-28.

Perloff, Marjorie. The Futurist Moment: Avant-Garde, Avant Guerre, and the Language of Rupture. Chicago: U of Chicago P, 1986.

Paglia, Camille. Sexual Personae. New York: Vintage, 1990.

Plath, Sylvia. Collected Poems. Ed. Ted Hughes. London: Faber and Faber, 1981.

Ronell, Avital. [Interview with Andrea Juno]. In Juno and Vale, Angry Women. 127-53.

Reuter. "Japan Apologizes to S. Korea for Past." Edmonton Journal (17 Jan 1992), B8.

Rich, Adrienne. The Fact of a Doorframe: Poems Selected and New, 1950-1984. New York: W.W. Norton, 1984.

Russell, Charles. Poets, Prophets and Rewolutionaries: The Literary Avant-Garde from Rimbaud through Postmodernism. New York: Oxford UP, 1985.

Solanis, Valerie. SCUM [Society for Cutting Up Men] Manifesto. New York: Olympia P, 1967/68; excerpts rep. in Sisterhood Is Powerful. Ed. Robin Morgan. New York: Vintage, 1970. 577-83.

Sorel, Georges. Reflections on Violence. Trans. T.E. Hulme. 1906; London: Collier-Macmillan, 1950.

Spinster, Sidney. "Warriors of the Luniform Shield: Lesbians and Direct Action." Fight Back: Feminist Resistance to Male Violence. Eds. Frédérique Delacoste and Felice Newman. Minneapolis: Cleis P, 1981. 306-11.

Suleiman, Susan Robin. Subversive Intent: Gender, Politics, and the Avant-Garde. Cambridge, MA: Harvard UP, 1990.

Sypnowich, Paula. "An Incitement to Violence." In Malette and Chalouh, The Montreal Massacre. 128-31.

Thomas, Don. "Female Students Worried By Graffiti." Edmonton Journal, 26 Jan. 1992.

Whitford, Margaret. "Identity and Violence." Luce Irigaray: Philosphy in the Feminine. London: Routledge, 1990. 12348.

Wittig, Monique. Les Guérillères. Trans. David Le Vay. 1969; London: Peter Owen, 1971.

Wittig, Monique. "The Trojan Horse." Lesbian Philosophies and Cultures. Ed. Jeffner Allen. 1984; New York: SUNY, 1990. 347-54. 